\title{
Ludic-activities-based therapeutic suitcase for rehabilitation of people with stroke
}

\author{
Mala terapêutica baseada em atividades lúdicas \\ para reabilitação de pessoas com AVC
}

\section{Maleta terapéutica basada en actividades lúdicas para la rehabilitación de personas con accidente cerebrovascular}

\author{
Jordana Liliam Stefanello $\circledast^{[a]}$, Giorgia Caroline Mendes $\circledast^{[b]}$, Auristela Duarte de Lima Moser $\oplus^{[a]}$, \\ Percy Nohama $\circledast^{[a, b] *}$
}

[a] Pontifícia Universidade Católica do Paraná (PUC-PR), Curitiba, PR, Brazil

${ }^{[b]}$ Universidade Tecnológica Federal do Paraná (UTFPR), Curitiba, PR, Brazil

\begin{abstract}
Introduction: The rehabilitation of people who suffered a stroke depends on patient commitment, rehabilitation strategies and technologies employed. Objective: To develop a suitcase with rehabilitation activities using devices that provide functional exercises in a fun and motivating way. Method: The main motor and sensory functions lost due to the stroke were identified and a set of three boards was modeled, providing activities with adequate structure and strategies to conduct rehabilitation exercises. A pilot experiment was performed with a subject with poststroke sequelae. Results: The suitcase has three boards containing devices for exercises of proprioception, motor coordination, grasping and reeducation to decrease agnosia, to increase muscle strength and for cognitive training. Conclusion: The suitcase fulfilled its functional reeducation purpose via a playful
\end{abstract}

\footnotetext{
* JLS: MS, e-mail: jordana.stefanello@outlook.com GCM: MS, e-mail: gicaroline@yahoo.com.br ADLM: PhD, e-mail: auristela.lima@pucpr.br PN: PhD, e-mail: percy.nohama@pucpr.br
} 
method; it provides improvements in the ability to fit parts, differentiate colors, recognize shapes and textures, and increase the strength.

Keywords: Stroke. Rehabilitation. Proprioception. Exercise. Muscle Strength.

\section{Resumo}

Introdução: A reabilitação das pessoas que sofreram acidente vascular encefálico depende do empenho do paciente e das estratégias e tecnologias de reabilitação empregadas. Objetivo: Desenvolver uma maleta com atividades reabilitatórias por meio de dispositivos que proporcionem, de forma lúdica e motivadora, exercícios funcionais. Método: Identificou-se as principais funções motoras e sensoriais perdidas em decorrência do AVE e modelou-se pranchas de atividades contendo estrutura e estratégias adequadas à realização de exercícios reabilitatórios. Realizou-se um ensaio piloto com um indivíduo que sofreu AVE. Resultados: A maleta possui três pranchas envolvendo dispositivos para exercícios de propriocepção, coordenação motora, pinça fina e reeducação para diminuição da agnosia, para aumento de força muscular e para treino cognitivo. Conclusão: A maleta confeccionada cumpriu seu intuito de reeducação funcional pela ludicidade, proporcionando melhora na habilidade de encaixe de peças e diferenciação de cores bem como no aumento de força e no reconhecimento de formas e texturas.

Palavras-chave: Acidente Vascular Cerebral. Reabilitação. Propriocepção. Exercício. Força Muscular.

\section{Resumen}

Introducción: La rehabilitación de las personas que han sufrido accidente cerebrovascular, depende del empeño del paciente y de las estrategias y tecnologías empleadas. Objetivo: Desarrollar una maleta con actividades de rehabilitación a través de dispositivos que proporcionen, de forma lúdica y motivadora, ejercicios funcionales. Método: Se identificaron las principales funciones motoras y sensoriales perdidas como consecuencia del accidente cerebrovascular, y se modelaron tableros de actividades con contenido, estructura y estrategias adecuadas a la realización de ejercicios de rehabilitación. Se realizó una prueba piloto con un individuo típico. Resultados: La maleta tiene tres tableros que involucran dispositivos para la propiocepción, coordinación motora, pinza fina y reeducación para disminuirla agnosia, aumentar la fuerza muscular y el entrenamiento cognitivo. Conclusión: La maleta confeccionada, cumplió su propósito de reeducación funcional de una manera lúdica, mejorando la habilidad de encaje de piezas y diferenciación de colores, así como el aumento de fuerza y el reconocimiento de formas y texturas.

Palabras clave: Accidente Cerebrovascular. Rehabilitación. Propiocepción. Ejercicio Físico. Fuerza Muscular. 


\section{Introduction}

The primary function of the central nervous system (CNS) constitutes in processing information that reaches it through the peripheral nervous system, so that motor responses occur [1].

Cerebrovascular diseases are more disabling than fatal. They have high incidence in Brazil and constitute the most common cause of neurological disability in the world [2].

An injury to the motor area of the CNS causes initial acute paralysis of the corresponding part on the opposite side of the body. The psychomotor area is responsible for coordinating movements and their effectiveness. Injuries in that area may cause apraxia, preventing daily activities such as dressing up, devices manipulation or necessary motor coordination to write [3]. Stroke is defined as the installation of a vascular origin syndrome that may cause motor, cognitive or sensory disorders, and in some cases lead to death [4].

Motor deficits can be classified as hemiplegia, absence of movement, or hemiparesis, absence of muscle strength, usually affecting the side of the body opposite to the injury. The extent, location, blood flow and early treatment for stroke victims determine the severity of neurological deficits [5].

Rehabilitation is essential for victims of stroke, and can prevent and revert dysfunctions, maximizing the individual's functional capacity. Therefore, the choice of rehabilitation technique is decisive for the success of the treatment. After stroke, the patient suffers from the so-called disuse phenomenon, and quickly starts using compensatory strategies [6]. Then, the sooner rehabilitation starts, the fewer skills will be lost.

As the recovery of upper limb functions after stroke is generally slower and rehabilitation has provided better results in lower limbs, the creation of therapies focused on the upper limbs is essential. The process of relearning takes place dynamically and can be controlled from external stimuli, since motor development is a sequential and continuous process by which the human being acquires motor skills, whose progress occurs from simple and disorganized movements to highly organized and complex motor skills [7].

Relearning is a process by which the individual organizes available resources and gains a profitable control on this organization. CNS learns essentially by performing the activity, although also through observation but without the same effectiveness of the active learning [4]. It is known that the stroke reduces the person's mobility, limiting his/her daily activities, hindering his/her movement and depriving him/her of performing satisfying and pleasurable activities [8, 9]. For many patients, therapy is not only the time to perform rehabilitation treatment, but also the moment of interaction with other patients. Increasingly, it is essential to make rehabilitation more attractive, efficient and fun, since instigation to perform certain activity, action or movement generates greater curiosity and satisfaction, making physiotherapy better and more present in the patient's life.

The project described here aimed to develop a therapeutic suitcase to play motor, proprioception and cognitive activities in individuals with stroke sequelae. The proposed equipment makes use of the new concept of rehabilitation through serious games. Thus, it makes possible to take people's treatment wherever they are through activities and functional exercises, carried out in a participatory and fun manner and it may be applied regardless of gender or age, for patients with cognitive ability preserved.

The suitcase's ludic activities are stimulating and challenging, which induce the individual to wish performing them as a game, and consequently, producing quicker beneficial effects on the patient. When two or more therapies are applied together, the results are more beneficial because they are more prolonged and their effects added. Thus, when active therapy is associated to conventional therapy, the results are more profitable although it can be used exclusively.

Potential beneficiaries of the therapeutic suitcase are people diagnosed with stroke (or who suffered traumatic brain injury) who have motor impairments, with cognitive abilities preservation, excluding patients in the hospital phase or other severe impairments such as vision, hearing, or contractures of upper limbs, which require the evaluation of fine motor coordination, tactile sensitivity and proprioception.

\section{Methods}

The designed suitcase was manufactured as a prototype, however, with all the functionalities of a definitive device. The following criteria were established for manufacturing: visually attractive materials to promote playfulness; easy distinction among pieces; light, resistant and portable; low-cost to enable reproducibility and general use. 
After that, the materials were selected to compose three boards organized in three difficulty levels, in ascending sequence. Board 1 has three elements created for exercises evoking proprioception and one for motor coordination and reeducation for agnosia. Board 2 has three devices related to proprioception, three for motor coordination training and fine prehension: two for increasing muscle strength and one for fine prehension and cognitive training. Board 3 contains eight exercises for training motor coordination and reeducation to reduce agnosia.

A 10-session training with 30-minutes duration, three times a week, was proposed. After this treatment, a clinical reevaluation would be applied to quantify the obtained improvement.

This study was approved by the Research Ethics Committee of Federal Technological University of Paraná, CAAE: 69155117.6.0000.5547.

To verify the suitability of the developed suitcase, a pilot essay was performed with a 46-year-old male, with a sequela of ischemic stroke occurred three years and seven months before, with preserved cognitive abilities. For three years, he has been treated with conventional physiotherapy combined with hydrotherapy. At the initial examination, it was verified a decrease in muscle strength in fingers equivalent to level 2 according to the Oxford scale, difficulty in pincer-mode grasping and decreased proprioception in the injured hemidium.

The therapeutic suitcase was presented to the patient with clarifications about the created rehabilitation activities' aims and how to handle them.

\section{Results}

The therapeutic suitcase (Figures 1 and 2) is made up of rigid and resistant wood to protect its contents of mechanical shocks. It has a strap to hold and transport and to make it possible to be taken to the patient; with three boards inside containing the proposed activities.

Board 1 has a children's playset (Figure 1.1), which has pieces of different shapes and three balls placed on the sides of the board. Each ball has a different texture and density for coordination training, cognitive ability and proprioception. This board must be placed in front of the patient. The therapist must demonstrate the activity and give the command to the patient to perform it.

It is also recommended that the activity with balls be accomplished with the board over the patient's legs with the therapist holding it. This activity is intended to train proprioception and can be performed with closed or open eyes, according to the patient's progress. They slide their fingertips over the balls and then the entire palmar region, first on the dark green ball (Figure 1.2) which is softer and smoother, which makes it possible to tighten the ball and feel its texture. Then they can move on to the second light green ball (Figure 1.3) which has a velvety texture and is slightly less soft. The third ball is the red one (Figure 1.4) which contains remarkable dotted high relief, with dots of $3 \mathrm{~mm}$ high.

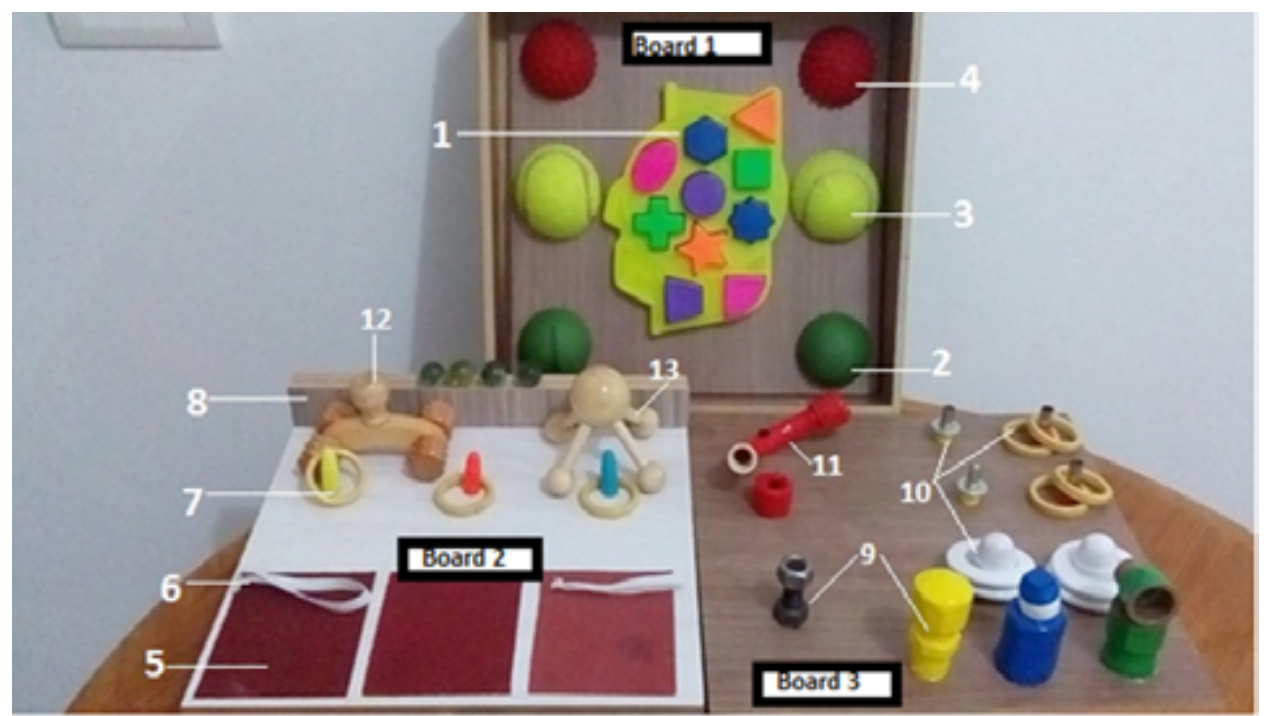

Figure 1- Open therapeutic suitcase showing the three boards for different proposed activities, including colored pieces, pins and rings. 


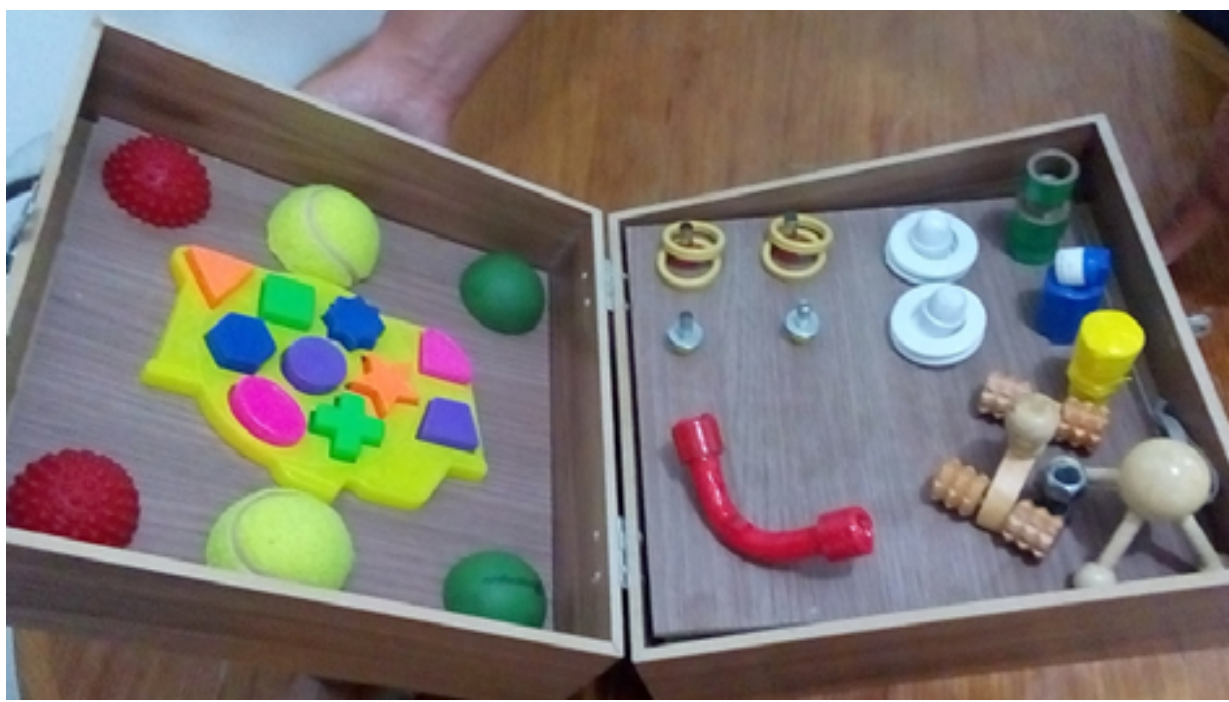

Figure 2 - Semi-enclosed therapeutic suitcase with the boards already stored showing the proposal of transport facility.

In the activity described, the therapist may ask the patient about the softest ball, the most important and their texture preference and ask them to describe the balls' texture with closed eyes. In this same activity, the patient accomplishes flexion and extension movements of the elbow and shoulder to reach the balls, promoting the elongation of the upper limb. If necessary, the therapist must intervene and assist in the obtention of maximum elongation supported by the patient or until s/he reaches the ball s/he wants.

Board 2 has three rectangular sandpapers with different textures, two elastics positioned one on each side of the board, three colored pins: green, orange and blue; three rings to be fitted on these pins, and a duct with ten balls to be moved on it.

The purpose of the sandpaper is proprioceptive training. The elastics are used to strengthen the musculature of fingers' phalanges and to coordinate the activity with both hands simultaneously. The purpose of the colored pins is the cognitive training to identify colors, motor coordination and re-education for agnosia when fitting rings in the requested pin. The channel will be used to improve coordination in moving little balls with fingertips without knocking them down, and the cognitive ability will be trained by doing simple mathematical operations such as addition and subtraction, proposed by the therapist.

This board should be placed on a table, within patient's reach, who should follow the therapist's instructions by performing the activities with one hand at first and then simultaneously with both hands, feeling the textures of the sticks (Figure 1.5) with closed and open eyes. The therapist should ask questions about the sandpapers textures and ask the patient to classify them from the roughest to the smoothest.

The next activity is to fit the patient's fingers inside the elastic ring fixed on the sides of the board, straining it to abduct the fingers, once the manual resistance exercises are important in the initial strengthening [10]. Instructed by the therapist, the patient must perform the activity with one hand at first and then with both hands simultaneously in a workout with ten repetitions. Then, under the therapist's command, the rings will be inserted into the pins (Figure 1.7). The therapist must be creative and play with the patient asking him to put a ring with his right hand into the green pin localized on the left side of the board, or ask him to put the three rings into the color pin that pleases the patient. Thus, the activity becomes more enjoyable and fun.

In this activity, the patient will have to make movements with the entire upper limb, because the therapist will ask to fit the rings in a contralateral manner, to make the movements more complex. This activity trains cognition, attention, coordination and helps in the active-assisted mobilization of the upper limbs. Coordination exercises are used to improve the function of upper limb by means of coarse and fine coordination, they should be played with smooth movements and several repetitions.

The last activity of this board consists in a rail containing a central lengthwise groove (Figure 1.8) and ten little glass balls, whereby the therapist should 
ask the patient to move them, one at a time, with the tip of one of his/her fingers, and then using two, three and four fingers. This exercise must be performed with both hands, and the therapist should ask the patient to perform small and easy mathematical operations so that the patient trains cognitive abilitiy and motor coordination, separating the balls on each extreme of the rail. These activities must not be continued upon reaching the threshold of pain or fatigue. If the speed and accuracy of movement decreases, exercises must be discontinued [10].

Board 3 involves four activities with screw threads of different sizes and shapes (Figure 1.9), six pins for engaging in rings (Figure 1.10), and an elbow-format piece (Figure 1.11) for fitting in pieces; all of different colors and sizes, in order to train motor coordination and prehension.

The therapist puts the board in front of the patient, preferably on a flat and firmly stable table, since the patient needs to apply some strength to achieve the activities. Firstly, the therapist defines the color and the piece to be threaded, but later the patient may choose the pieces; thus stimulating him to think and decide which device to use.

Inside the suitcase there is also a device like a car (Figure 1.12) which allows us to slide and produce extension and flexion movements with elbow and shoulder. Another piece inserted corresponds to a wooden ball (Figure 1.13) with four supports, which aims to evoke the ulnar and radial deviation movement.

\section{Pilot experiment}

After the clinical examination, all activities of the therapeutic suitcase were presented to the volunteer.

Firstly, we proposed that the volunteer fit the most difficult pieces in the game, Board 1, Figure 1.1, not letting him choose the pieces to avoid the selection of the easiest ones. In this way, at the end there would be fewer spaces and fewer pieces, making it difficult to fit and requiring more skill. Secondly, the volunteer should decide where he would put the piece because he could not pick up one and test it in several places. The move should be "accurate", and the volunteer should choose the location and place the piece at the same time. Thirdly, we asked the patient to feel with hands, and to describe the sensation of textures of the three lateral balls, with open and closed eyes.
Afterwards, board 2 was presented to the volunteer. He was oriented to touch the sandpapers, feel their textures and insert the rings on the pins, roll the little glass balls in the rail's groove, one at a time, and perform the extension of fingers on the elastic bands, for muscle strengthening.

On board 3, the patient was instructed to fit the screws on the threaded nuts and rings into pins, each one of a different size, training fine coordination and muscular strength.

The patient was treated with the board 1 and 2 up to the sixth session, when we observed improvement on his ability to fit pieces, to differentiate colors, and better recognize shapes and textures without the aid of vision.

From the sixth to the eighth session, he used all three boards. In this period, we noticed improvement in the movements (hoop fitting in pin 2), he improved agility and increased scoring on the Oxford scale (from 2 to 5 ). These gains determined the abandon of board 1 .

From the eighth session, the application of boards 2 and 3 resulted on patient's improvement in his ability of pincer grasp and fine motor coordination, since the exercises were performed with greater assertiveness and agility. In general, these results provided a satisfactory return to his activities of daily living (ADLs).

\section{Discussion}

There has been a big discussion about the best therapeutic means to functionally restore individuals after stroke, to broaden their inclusion in society and reinsert them in their ADL. Activities should have a rehabilitative role, however, when adapted for a recreational or playful mode, as proposed in this project, it potentializes their purposes [11].

From the pilot essay, it was observed improvement in the ability to fit parts and color differentiation, and better recognition of shapes and textures without the aid of vision. In this sense, the proposed activities have reached the requirements for playfulness and recreation purposes. The elements that compose the suitcase present features that instigate and hold the attention of the patient, assisting him in the cognitive reeducation. These characteristics are fundamental in this process aiming to restore or stimulate functional and cognitive abilities of the human being or rebuild their cognitive resources [12]. 
Learning with playfulness is more efficient at all ages because playful activities arouse interest in the individual and has real daily components $[13,14]$.

With the continuation of the treatment, there was improved flexibility and increased score in Oxford scale (2 to 5), showing that psychomotor practice promotes reeducation by means of adjustments in tonic activity, bettering motor control [14]. This evolution is also due to neuroplasticity phenomenon, which occurs due to the brain's ability to learn and change, because the cells of other areas that were not affected by the stroke may assume certain functions once performed by affected cells [15]. On the other hand, the improvement in the ability to perform prehension in the pincer mode and fine motor coordination leads to a satisfactory return to the ADLs and reintegration into society, since the lack of ability to produce and regulate voluntary movement, inadequate activation of muscles and decreased joint mobility changes the postural coordination $[16,17]$.

In a study with patients affected by stroke who underwent upper limb active exercises, it was found that there was a significant improvement in the degree of muscle strength and ability to perform functional movements, and none of the patients had incidence of shoulder pain after the treatment [18] The proposed suitcase reproduces everyday activities indirectly, and can be used both in the acute phase (to preserve the brain engram) as well as in the chronic phase [19].

In a study carried out by Lima et al., with 28 individuals affected by stroke, 25 of them had sensorial deficits in hand and wrist, with reduction of proprioception and tactile sensitivity, requiring rehabilitation [20]. For this purpose, the therapeutic suitcase described here owns devices for activities with the specific objective of treating sensitivity and proprioception, with relevant gains in the first 10 sessions, as shown in the pilot essay.

Patients with stroke who have both sensory and motor deficits have worse prognosis than those with motor deficits alone. The consequences of somatosensory changes include changes in recognition and handling objects, susceptible to burns and wounds in the limbs, loss of motor control in the affected limb and difficulty in controlling the level of muscle strength $[21,22]$.
Therefore, these patients need to be continuously in the rehabilitation process to restore their abilities and obtain somatosensorial gains [14,23].

Although this type of approach based on playful activities is infrequent in the rehabilitation of patients with chronic stroke [24], the commonalities among several of the effective interventions include the use of goal-directed, individualized tasks that promote frequent repetitions of task-related or task-specific movements [25]. Thus, this study demonstrates the importance of creativity in therapeutic approaches making them more stimulating and playful. In addition, the suitcase built is inexpensive and can be reproduced by patients to be used with people of all ages.

The incorporation of those tools into clinical practice needs a pilot test with a larger number of patients to validate its usability and improve its possibilities of use valuing the playfulness and its therapeutic possibilities [26].

\section{Conclusion}

The pilot essay showed that the suitcase was efficient and challenging for the volunteer, motivating him to carry out the activities. This was evidenced through his enthusiasm during the accomplishment of the therapeutic activities. To evoke playfulness and creativity as a means for rehabilitation helps individual to search his goals in a pleasurable way, overcoming challenges and reeducating his capabilities and abilities.

Exercises for motor coordination should start at tolerable levels and, then, be increased as the coordination tasks extend. They may be improved by increasing speed, changing the size of objects used or incorporating other tools into activities.

The pilot essay results allow us to affirm that the suitcase may be applied on reeducation of coarse and fine motor coordination, proprioception, tactile sensitivity, precision and agility, in a playful and motivating way. However, additional studies will be developed for its clinical validation.

\section{Acknowledgments}

The authors are grateful to the National Council for Scientific and Technological Development (CNPq) for the scholarships. 


\section{References}

1. Valle J. Neurofisiologia geral, notas de estudo de bioquímica. Guarulhos: Unipar; 2009.

2. Pontes-Neto OM, Silva GS, Feitosa MR, Figueiredo NL, Fiorot JA Jr, Rocha TN, et al. Stroke awareness in Brazil: alarming results in a community-based study. Stroke. 2008;39(2):292-6.

3. Vitória P. Fisioterapia prática. Rio de Janeiro: Guanabara Koogan; 2010.

4. World Health Organization. WHO STEPS stroke manual: the WHO STEPwise approach to stroke surveillance/noncommunicable diseases and mental health. Geneva; 2006.

5. Oxford D, Moura EW, Lima E, Silva, PAC. Fisioterapia: aspectos clínicos e práticos da reabilitação. São Paulo: Artes Médicas; 2007.

6. Vaz DV, Alvarenga RF, Mancini MC, Pinto TPS, Furtado SRC, Tirado MGA. Terapia de movimento induzido pela restrição na hemiplegia: um estudo de caso único. Fisioter Pesqui. 2008;15(3):298-303.

7. Haywood KM, Getchell, N. Desenvolvimento motor ao longo da vida. 3rd ed. Porto Alegre: Artmed; 2004.

8. Klotz T, Borges HC, Monteiro VC, Chamlian TR, Masiero D. Tratamento fisioterapêutico do ombro doloroso de pacientes hemiplégicos por acidente vascular encefálico-Revisão da Literatura. Acta Fisiatr. 2006;13(1):12-16.

9. Costa AM, Duarte E. Atividade física e a relação com a qualidade de vida, de pessoas com sequelas de acidente vascular cerebral isquêmico (AVCI). Rev Bras Cienc Mov. 2002;10(1):47-54.

10. Borges IPC, Furtado LS, Gonçalves RS. Dispositivo robótico para reabilitação da mão humana. Proceedings of the $10^{\text {th }}$ Congresso de Estudos Literários; 2012 Sept 24-28; Uberlândia, Brazil. 2012.

11. Calil SR, Santos TA, Braga, DM, Labronici, RHD. Reabilitação por meio da dança: uma proposta fisioterapêutica em pacientes com sequela de AVC. Rev Neurocienc. 2007;15(3):195-202.
12. Cancela DMG. O acidente vascular cerebral: classificação, principais consequências e reabilitação. 2008 [acesso 2018 Oct 5]. Avialable from: https://tinyurl.com/uqb7cck

13. Lopes MG. Jogos na educação: criar, fazer, jogar. 2nd ed. São Paulo: Cortez; 1999.

14. Carey LM, Matyas TA, Baum C. Effects of somatosensory impairment on participation after stroke. Am J Occup Ther. 2018;72(3):7203205100p1-7203205100p10.

15. Falcão HT, Barreto MAM. Breve histórico da psicomotricidade. Ensino, Saude Ambiente. 2009;2(2):84-96.

16. Turville M,Carey LM, MatyasTA,BlennerhassettJ.Change in functional arm use is associated with somatosensory skills after sensory retraining poststroke. Am J Occup Ther. 2018;71(3):7103190070p1-7103190070p9.

17. Mejia D, Oliveira LL. A importância do tratamento precoce em pacientes hemiplégico, no processo de reaprendizagem motora após o acidente vascular encefálico [dissertation]. Goiânia: Faculdade Ávila; 2007.

18. Horn AI, Fontes SV, Carvalho SM, Silvado RA, Barbosa PM, Alcides D, et al. Cinesioterapia previne ombro doloroso em pacientes hemiplégicos, paréticos na fase sub- aguda do acidente vascular encefálico. Arq Neuropsiquiatr. 2003;61(3B):768-71.

19. Paula GR, Beber BC, Baggio SB, Petry T. Neuropsicologia da aprendizagem. Rev Psicopedag. 2006;23(72):224-31.

20. Lima NM, Menegatti KC, Yu É, Sacamoto NY, Scalha TB, Lima IN, et al. Sensory deficits in ipsilesional upper-extremity in chronic stroke patients. Arq Neuropsiquiatr. 2015;73(10):834-9.

21. Scalha TB, Miyasaki E, Lima NM, Borges G. Correlations between motor and sensory functions in upper limb chronic hemiparetics after stroke. Arq Neuropsiquiatr. 2011;69(4):624-9.

22. Gordon GM. Neurocognitive rehabilitation: skills or strategies? Am J Occup Ther. 2018;72(6):7206150010p1-7206150010p16. 
23. Massie $\mathrm{C}$, White $\mathrm{C}$, Funke D. Impact of motor practice on neuromodulation for stroke rehabilitation. Am J Occup Ther. 2016;70(4 Suppl 1):7011505107p1.

24. Skubik-Peplaski C, Carrico C, Nichols L, Chelette K, Sawaki L. Behavioral, neurophysiological, and descriptive changes after occupation-based intervention. Am J Occup Ther. 2012;66(6):488-93.

25. Nilsen DM, Gillen G, Geller D, Hreha K, Osei E, Saleem GT. Effectiveness of interventions to improve occupational performance of people with motor impairments after stroke: an evidence-based review. Am J Occup Ther. 2014;69(1):6901180030p1-6901180030p9.
26. Mendonça TC, Macedo AB. A importância do lúdico durante o tratamento fisioterapêutico em pacientes idosos com déficit cognitivo: estudo de caso. Saúde CESUC. 2010;(1).

Received in 11/12/2018

Recebido em 12/11/2018

Recibido en $12 / 11 / 2018$

Approved in 08/26/2019

Aprovado em 26/08/2019

Aprobado en 26/08/2019 
In the article "Ludic-activities-based therapeutic suitcase for rehabilitation of people with stroke", DOI number: http://dx.doi.org/10.1590/1980-5918.032.A045, published in Revista Fisioterapia em Movimento, v. 32, e003245, 2019, (http://www.scielo.br/scielo.php?script=sci_arttext\&pid=S0103-51502019000100240\&tlng=en), on page 1:

\section{Where it reads:}

\section{Abstract}

Introduction: Osteoarthritis (OA), the most common form of arthritis, is considered the main cause of pain and disability in elderly people. Objective: To evaluate the effect of systematic muscle strength training on functional performance and quality of life in individuals with knee OA. Method: Subjects with knee OA ( $\mathrm{n}=27,46-76$ year-old) completed the Western Ontario and McMaster Universities Osteoarthritis Index (Womac), Medical Outcomes Short-Form 36-item Health Survey (SF-36), and Visual Analog Scale (VAS) questionnaires, musculoskeletal assessments, and 10-repetition maximum and timed 10-meter walk tests both before and after training. The training consisted in an exercise resistance program and stretches for twelve weeks (three sessions of 80 minutes per week). Results: Twenty-two individuals completed the training. Reduced overall scores and Womac physical function indicated improved functional performance $(p<0.001)$ as well as increased gait speed $(p<0.001)$. The perception of pain decreased after training, as evidenced by the VAS, Womac pain domain, and SF-36 scores $(\mathrm{p}<0.001)$. Quality of life improvements occurred primarily in the areas of pain, functional capacity, and SF-36 physical aspects. No change in body mass index was noted $(p=0.93)$. Conclusion: Our results indicate that the combination of resistance training for the quadriceps, gluteus, and abdominal muscles could be a viable alternative to improving functionality and quality of life in patients with knee OA. However, more studies are necessary to confirm our findings.

Keywords: Osteoarthritis. Pain. Quality of Life. Resistance Training.

\section{Resumo}

Introdução: A osteoartrite (OA) é a forma mais comum de artrite, considerada a principal causa de dor e incapacidade em idosos. Objetivo: Avaliar o impacto de um treinamento sistematizado de resistência muscular no desempenho funcional e na qualidade de vida em indivíduos com OA de joelho. Método: Voluntários com OA de joelho ( $n=27,46-76$ anos) foram submetidos, antes e depois do período de treinamento, à aplicação dos questionários de Womac e SF-36 e da Escala Visual Analógica (EVA), à avaliação musculoesquelética, teste de 10 RM e teste de caminhada de dez metros. $O$ treinamento consistiu em um programa de resistência muscular e alongamentos, por doze semanas (três sessões de 80 minutos por semana). Resultados: Vinte e dois indivíduos concluíram o treinamento. As reduções nos escores globais e de função física do Womac indicam melhoria no desempenho funcional $(p<0,001)$, assim como o aumento da velocidade da marcha $(p<0,001)$. A percepção 
da dor diminuiu após o treinamento, como demonstram os resultados da VAS e do domínio dor do Womac e do SF-36 ( $p$ <,001). A melhoria da qualidade de vida ocorreu principalmente por modificações nos domínios de dor, capacidade funcional e aspectos físicos do SF-36. Não houve alteração no IMC ( $p=0,93)$. Conclusão: Os resultados indicam que a combinação de exercícios de resistência dos músculos quadríceps, glúteos e abdômen pode ser estratégia viável para melhorar a funcionalidade e a qualidade de vida desses pacientes. Entretanto, mais estudos são necessários para investigar a questão.

Palavras-chave: Osteoartrite. Dor. Qualidade de Vida. Treinamento de Resistência.

\section{Resumen}

Introducción: La osteoartritis (OA) es la forma más común de artritis, considerada la principal causa de dolor e incapacidad en los ancianos. Objetivo: Evaluar el impacto de un entrenamiento sistematizado de resistencia muscular en el desempeño funcional y la calidad de vida en individuos con OA de rodilla. Método: Se sometieron a voluntarios con $O A$ de rodilla $(n=27,46-76$ años), antes y después del período de entrenamiento, a la aplicación de los cuestionarios WOMAC y SF-36, la Escala Visual Analógica (EVA), la evaluación musculoesquelética, prueba de 10 RM y prueba de caminata de diez metros. El entrenamiento consistió en un programa de resistencia muscular y estiramientos por 12 semanas (3 sesiones de 80 min semanales). Resultados: 22 individuos concluyeron el entrenamiento. Las reducciones en los escores globales $y$ de función física de WOMAC indican mejorar el desempeño funcional $(p<0,001) y$ aumentar la velocidad de la marcha $(p<0,001)$. La percepción del dolor disminuyó después del entrenamiento, como lo demuestran los resultados de VAS y de los dominios dolor del WOMAC y SF-36 ( $p<0,001)$. La mejora de la calidad de vida ocurrió principalmente por modificaciones en los dominios del dolor, capacidad funcional y aspectos físicos del SF-36. No se alteró el IMC ( $p=0,93)$. Conclusión: La combinación de ejercicios de resistencia de los músculos cuadríceps, glúteos y abdomen puede ser una estrategia viable para mejorar la funcionalidad y la calidad de vida de pacientes con $O A$ de rodilla. Pero más estudios son necesarios para investigar la cuestión.

Palabras clave: Osteoartritis. Dolor. Calidad de vida. Entrenamiento de Resistencia.

\section{It should read}

\section{Abstract}

Introduction: The rehabilitation of people who suffered a stroke depends on patient commitment, rehabilitation strategies and technologies employed. Objective: To develop a suitcase with rehabilitation activities using devices that provide functional exercises in a fun and motivating way. Method: The main motor and sensory functions lost due to the stroke were identified and a set of three boards was modeled, providing activities with adequate structure and strategies to conduct rehabilitation exercises. A pilot experiment was performed with a subject with poststroke sequelae. Results: The suitcase has three boards containing devices for exercises of proprioception, motor coordination, grasping and reeducation to decrease agnosia, to increase muscle strength and for cognitive training. Conclusion: The suitcase fulfilled its functional reeducation purpose via a playful method; it provides improvements in the ability to fit parts, differentiate colors, recognize shapes and textures, and increase the strength.

Keywords: Stroke. Rehabilitation. Proprioception. Exercise. Muscle Strength. 


\section{Resumo}

Introdução: A reabilitação das pessoas que sofreram acidente vascular encefálico depende do empenho do paciente e das estratégias e tecnologias de reabilitação empregadas. Objetivo: Desenvolver uma maleta com atividades reabilitatórias por meio de dispositivos que proporcionem, de forma lúdica e motivadora, exercícios funcionais. Método: Identificou-se as principais funções motoras e sensoriais perdidas em decorrência do AVE e modelou-se pranchas de atividades contendo estrutura e estratégias adequadas à realização de exercícios reabilitatórios. Realizou-se um ensaio piloto com um indivíduo que sofreu AVE. Resultados: A maleta possui três pranchas envolvendo dispositivos para exercícios de propriocepção, coordenação motora, pinça fina e reeducação para diminuição da agnosia, para aumento de força muscular e para treino cognitivo. Conclusão: A maleta confeccionada cumpriu seu intuito de reeducação funcional pela ludicidade, proporcionando melhora na habilidade de encaixe de peças e diferenciação de cores bem como no aumento de força e no reconhecimento de formas e texturas.

Palavras-chave: Acidente Vascular Cerebral. Reabilitação. Propriocepção. Exercício. Força Muscular.

\section{Resumen}

Introducción: La rehabilitación de las personas que han sufrido accidente cerebrovascular, depende del empeño del paciente y de las estrategias y tecnologías empleadas. Objetivo: Desarrollar una maleta con actividades de rehabilitación a través de dispositivos que proporcionen, de forma lúdica y motivadora, ejercicios funcionales. Método: Se identificaron las principales funciones motoras y sensoriales perdidas como consecuencia del accidente cerebrovascular, y se modelaron tableros de actividades con contenido, estructura y estrategias adecuadas a la realización de ejercicios de rehabilitación. Se realizó una prueba piloto con un individuo típico. Resultados: La maleta tiene tres tableros que involucran dispositivos para la propiocepción, coordinación motora, pinza fina y reeducación para disminuirla agnosia, aumentar la fuerza muscular y el entrenamiento cognitivo. Conclusión: La maleta confeccionada, cumplió su propósito de reeducación funcional de una manera lúdica, mejorando la habilidad de encaje de piezas y diferenciación de colores, así como el aumento de fuerza y el reconocimiento de formas y texturas.

Palabras clave: Accidente Cerebrovascular. Rehabilitación. Propiocepción. Ejercicio Físico. Fuerza Muscular. 